Biotropica

November 2011, Volume 52, Issue 6, Pages 1183-1193

https://doi.org/10.1111/btp.12817

Archimer

https://archimer.ifremer.fr/doc/00634/74572/

\title{
Can light- saturated photosynthesis in lowland tropical forests be estimated by one light level?
}

Verryckt Lore T. 1, ${ }^{*}$, Ellsworth David S. ${ }^{2}$, Vicca Sara ${ }^{1}$, Van Langenhove Leandro ${ }^{1}$, Peñuelas Josep ${ }^{3,4}$, Ciais Philippe ${ }^{5}$, Posada Juan M. ${ }^{6}$, Stahl Clément ${ }^{7}$, Coste Sabrina ${ }^{8}$, Courtois Elodie A. ${ }^{9}$, Obersteiner Michael ${ }^{10}$, Chave Jérôme ${ }^{11}$, Janssens Ivan A. ${ }^{1}$

${ }^{1}$ Department of Biology University of Antwerp Wilrijk, Belgium

2 Hawkesbury Institute for the Environment Western Sydney University Penrith NSW ,Australia

${ }^{3}$ CREAF Barcelona, Spain

${ }^{4}$ CSIC Global Ecology CREAF-CSIC-UAB Barcelona, Spain

${ }^{5}$ Laboratoire des Sciences du Climat et de l'Environnement CEA-CNRS-UVSQ Gif-sur-Yvette ,France

${ }^{6}$ Biology Department Faculty of Natural Sciences Universidad del Rosario Bogotá, D.C. ,Colombia

7 INRA UMR Ecofog AgroParisTech CNRS Cirad Université des AntillesUniversité de Guyane

Kourou ,France

8 UMR Ecofog AgroParisTech CNRS Cirad INRA Université de Guyane Université des Antilles Kourou, France

${ }^{9}$ Laboratoire Ecologie, évolution, interactions des systèmes amazoniens (LEEISA) CNRS IFREMER

Université de Guyane Cayenne, French Guiana

10 International Institute for Applied Systems Analysis (IIASA) Laxenburg, Austria

11 UMR 5174 Laboratoire Evolution et Diversité Biologique CNRS Université Paul Sabatier ,Toulouse

France

*Corresponding author : Lore T. Verryckt, email address : lore.verryckt@uantwerpen.be

\begin{abstract}
:
Leaf-level net photosynthesis ( $\mathrm{n}$ ) estimates and associated photosynthetic parameters are crucial for accurately parameterizing photosynthesis models. For tropical forests, such data are poorly available and collected at variable light conditions. To avoid over- or underestimation of modeled photosynthesis, it is critical to know at which photosynthetic photon flux density (PPFD) photosynthesis becomes lightsaturated. We studied the dependence of A $n$ on PPFD in two tropical forests in French Guiana. We estimated the light saturation range, including the lowest PPFD level at which $A$ sat (A $n$ at light saturation) is reached, as well as the PPFD range at which $A$ sat remained unaltered. The light saturation range was derived from photosynthetic light-response curves, and within-canopy and interspecific differences were studied. We observed wide light saturation ranges of $A \mathrm{n}$. Light saturation ranges differed among canopy heights, but a PPFD level of $1,000 \mu \mathrm{mol} m-2 \mathrm{~s}-1$ was common across all heights, except for pioneer trees species that did not reach light saturation below $2,000 \mu \mathrm{mol} m-2 \mathrm{~s}-1$. A light intensity of $1,000 \mu \mathrm{mol} \mathrm{m}-2 \mathrm{~s}-1$ sufficed for measuring A sat of climax species at our study sites, independent of the species or the canopy height. Because of the wide light saturation ranges, results from studies measuring A sat at higher PPFD levels (for upper canopy leaves up to $1,600 \mu \mathrm{mol} m-2 \mathrm{~s}-1$ ) are comparable with studies measuring at $1,000 \mu \mathrm{mol} m-2 \mathrm{~s}-1$.
\end{abstract}




\section{INTRODUCTION}

Tropical forests are among the most productive ecosystems on earth, accounting for more than one third of global terrestrial gross primary productivity (GPP), and thereby playing an important role in the global carbon (C) cycle (Beer et al., 2010; Malhi, 2010). Global land surface models are used to quantitatively assess how tropical forest GPP will evolve under climate change. These models require a mechanistic understanding of photosynthesis and accurate estimates of regional photosynthetic parameters: $A_{\text {sat }}$ (the light-saturated leaf-level net photosynthetic rate; in $\mu \mathrm{mol} / \mathrm{m}^{2} / \mathrm{s}$ ), $V_{\text {cmax }}$ (the maximum carboxylation rate; in $\mu \mathrm{mol} / \mathrm{m}^{2} / \mathrm{s}$ ) and $J_{\max }$ (the electron transport rate supporting ribulose 1,5-phosphate (RuBP) regeneration; in $\left.\mu \mathrm{mol} / \mathrm{m}^{2} / \mathrm{s}\right)$. Tropical leaf-level photosynthesis data are much sparser than data gathered in temperate ecosystems (Cavaleri, Reed, Smith, \& Wood, 2015; Goldstein \& Santiago, 2016; Kattge, Knorr, Raddatz, \&

Wirth, 2009; Niinemets, Keenan, \& Hallik, 2015; Wu, Dijkstra, Koch, Peñuelas, \& Hungate, 2011). The knowledge gap in this biome leads to uncertainties and impedes our ability to predict the photosynthetic response of tropical forests to a changing environment.

There are several reasons why photosynthesis in the tropical biome is understudied, often related to the complications associated with measuring photosynthetic capacity. First, due to high species richness and functional group diversity(Fine, Ree, \& Burnham, 2008; Gentry, 1982) large variation in the photosynthetic capacity of tropical tree species occurs, requiring greater sample sizes than in other biomes (Kattge et al., 2011; Reich, Walters, \& Ellsworth, 1997). Second, photosynthesis measurement protocols have not been standardized. Leaf-level photosynthesis has, for example, been measured at different light levels and at different temperatures. Therefore, the leaf-level photosynthesis data required to parameterize land surface models are scarce and not always comparable, hampering accurate projections of tropical forest 
GPP, as well as global syntheses aimed at comparing photosynthesis among tropical forests or between tropical forests and other biomes. Finally, strong light gradients throughout the canopy exist in forests, resulting in a great variability of light conditions within the canopy (Niinemets, 2007). This effect is especially pronounced in tropical forests because of high leaf layering(Tianxiang et al., 2002; Zhu et al., 2016), and exacerbated by the spatial variation induced by canopy gaps, creating sharp gradients in light intensity (Iida et al., 2014). High variability in photosynthetic photon flux density (PPFD in $\mu \mathrm{mol}$ of photons $/ \mathrm{m}^{2} / \mathrm{s}$ ), and variability in how plants adjust to light intensity complicate determining $A_{\text {sat }}$ and estimating $V_{c \max }$ and $J_{\max }$, all key parameters of photosynthetic activity and critical for upscaling and modelling (Rogers et al., 2017).

Most land surface models simulate photosynthesis using the leaf biochemical model of Farquhar et al. (1980) (Fisher, Huntzinger, Schwalm, \& Sitch, 2014). Two key parameters in this model are $V_{\mathrm{cmax}}$ and $J_{\max }$ and they are typically derived from $A_{\mathrm{n}}-C_{\mathrm{i}}$ curves measured at light saturation. A reasonably accurate alternative way to derive $V_{\mathrm{cmax}}$ is through $A_{\text {sat }}$ measurements (De Kauwe et al., 2016). To avoid over- or underestimation of these parameters, and hence of photosynthesis, it is critical to know at which PPFD photosynthesis becomes light saturated, and above which PPFD photoinhibition causes reduced $A_{n}$. The PPFD levels at which light saturation is reached varies among tree species (Denslow, 1987) and with light acclimation of the leaves (Markesteijn, Poorter, \& Bongers, 2007; Rijkers, Pons, \& Bongers, 2000; Urban, Holub, \& Klem, 2017). The reported PPFD levels for $A_{\text {sat }}$ vary highly among studies, with reported values for upper canopy foliage of tropical rainforest ranging from $1000 \mu \mathrm{mol} / \mathrm{m}^{2} / \mathrm{s}$ (Doughty, 2011; Doughty et al., 2015; Slot \& Winter, 2017) over $1200 \mu \mathrm{mol} / \mathrm{m}^{2} / \mathrm{s}$ (Stahl et al., 2013; van de Weg, Meir, Grace, \& Ramos, 2012) and $1800 \mu \mathrm{mol} / \mathrm{m}^{2} / \mathrm{s}$ (Bahar et al., 2016; Domingues, Martinelli, \& 
Ehleringer, 2014; Weerasinghe et al., 2014) to $2000 \mu \mathrm{mol} / \mathrm{m}^{2} / \mathrm{s}$ (Rowland et al., 2015; Rowland et al., 2016; Santos et al., 2018). Leaves situated in the upper canopy are often in direct sunlight while leaves situated in the lower canopy are often shaded and thus acclimated to lower PPFD levels (Urban et al., 2017). Many studies have, therefore, used different PPFD settings when measuring $A_{\text {sat }}$ on sunlit upper or shaded lower canopy leaves (e.g. Domingues et al. (2014); Rowland et al. (2015); van de Weg et al. (2012)). The PPFD levels chosen in these studies were, however, not consistent and ranged between 1200 and $2000 \mu \mathrm{mol} / \mathrm{m}^{2} / \mathrm{s}$ for sunlit upper canopy leaves and between 500 and $1000 \mu \mathrm{mol} / \mathrm{m}^{2} / \mathrm{s}$ for shaded lower canopy and understory leaves (e.g. Domingues et al. (2014); Santos et al. (2018); van de Weg et al. (2012); Weerasinghe et al. (2014)). Although these light levels may be appropriate for the specific trees/leaves studied, it is usually unclear if light saturation was reached and photoinhibition avoided, hence obscuring inter-study comparisons.

Light levels that exceed the light saturation point may induce photoinhibition, defined as the slow, reversible decline of photosynthetic efficiency when absorbed light is in excess of that required for C assimilation (Demmig-Adams \& Adams III, 1992; Long, Humphries, \& Falkowski, 1994; Powles, 1984). Because of photoinhibition, measurements of $A_{\text {sat }}$ should not be conducted at excessive light conditions, and failure to do so would result in an underestimation of the maximal $\mathrm{C}$ uptake by the leaf, and hence by the ecosystem, significantly impacting the estimates of tropical forest C uptake (Clark et al., 2017).

We here studied the PPFD-dependence of leaf-level net photosynthesis $\left(A_{n}\right)$ and how this varies vertically within the canopy. We also identified the light saturation range, i.e. the PPFD levels across which $A_{\text {sat }}$ is maintained. Different tropical tree species were studied at two lowland tropical rainforests in French Guiana, contrasting climax versus pioneer trees. Climax species are 
slow-growing and shade-tolerant and form the great majority of tree species in a tropical rainforest, whereas pioneer trees are expected to live at high light levels, are shade-intolerant, and have high growth rates (Kitajima, 1994; Martinez-Camilo, Gonzalez-Espinosa, RamirezMarcial, Cayuela, \& Perez-Farrera, 2017; Raaimakers, Boot, \& Dijkstra, 1995; Swaine \& Whitmore, 1988). Identifying a common PPFD level at which $A_{n}$ saturates for lowland tropical trees would facilitate the comparisons between different tree species and height levels within the canopy. We hypothesize that the PPFD at which $A_{n}$ becomes light-saturated, the light saturation point, decreases vertically within the canopy due to shade acclimation, as has been observed for temperate forest species (Lewis, McKane, Tingey, \& Beedlow, 2000; Parra et al., 2015); and that it is higher for pioneer species than for shade-tolerant species since pioneers have higher growth rates and are less adapted to low light conditions (Martinez-Camilo et al., 2017; Raaimakers et al., 1995). We also hypothesize that at very high PPFD (much above the light saturation point), photoinhibition occurs irrespective of canopy position, but that this reduction in $A_{n}$ occurs at lower PPFD levels and is more pronounced for lower-canopy leaves that are more shadeadapted.

\section{METHODS}

\subsection{Study sites}

This study was conducted at two mature lowland tropical rainforest sites in French Guiana, South America. The climate at both sites is tropical humid, with a dry season lasting from August to November and a short dry spell in March. Mean daily temperature is $25.7^{\circ} \mathrm{C}$ in the dry season and $26.7^{\circ} \mathrm{C}$ in the rainy season. 
The first study site was located at the Paracou Research Station $\left(5^{\circ} 16^{\prime} \mathrm{N}, 52^{\circ} 16^{\prime} \mathrm{W}\right)$, characterized by an average annual rainfall of $3150 \mathrm{~mm} / \mathrm{y}(2015-2017)$. The density of trees with a DBH > $10 \mathrm{~cm}$ averaged ca. 620 trees/ha and average tree species richness is ca. 160 species/ha (Bonal et al., 2008). The mean canopy height is $35 \mathrm{~m}$, with emergent trees exceeding $40 \mathrm{~m}$. The second study site was situated at the Pararé site of the Nouragues Research Station $\left(4^{\circ} 02^{\prime} \mathrm{N}, 52^{\circ} 41^{\prime} \mathrm{W}\right)$, located $120 \mathrm{~km}$ south of Cayenne. This forest receives approximately 3000 mm rain/y (Bongers, Charles-Dominique, Forget, \& Théry, 2001). Tree species richness varies between 180 and 200 species/ha. The canopy height ranges between 30-40 m, with emergent trees reaching $60 \mathrm{~m}$ (Van Der Meer, Sterck, \& Bongers, 1998). The soils at both sites are characterized as nutrient-poor Acrisols (FAO, 1998)(FAO-ISRIC-ISSS 1998), with the soils at Paracou ranging from loamy sand to sandy loam and at Nouragues from sandy loam to silty clay according to the USDA texture classification chart (Van Langenhove et al., 2019). Both forest stands are equipped with an instrumentation tower. Meteorological measurements and measurements of ecosystem net $\mathrm{CO}_{2}$ exchange with the eddy covariance technique have been conducted on a continuous basis since 2003 in Paracou and since 2014 at Nouragues.

\subsection{Leaf gas exchange}

Leaf gas exchange measurements were carried out with a set of infrared gas analyzers (IRGAs) incorporated into a portable photosynthesis system (LI-6400XT, LI-COR, Lincoln, NE, U.S.A.). During measurements, a leaf was clamped within a chamber with controlled microenvironmental conditions and concentration changes of dihydrogen oxide $\left(\mathrm{H}_{2} \mathrm{O}\right)$ and carbon dioxide $\left(\mathrm{CO}_{2}\right)$ between incoming and outgoing air were measured. During the measurements, the relative humidity inside the leaf chamber was kept as close to ambient $(70 \pm 8 \%)$ as possible and the air 
flow rate was $500 \mu \mathrm{mol} / \mathrm{s}$. The chamber block temperature was controlled to minimize variation in leaf temperature and was set at $30 \pm 0.15^{\circ} \mathrm{C}$.

All leaf gas exchange measurements were performed on newly formed mature leaves from $2 \mathrm{~m}$-long excised and rehydrated branches, except for those measured on saplings (diameter 0.4-3.4 cm), which were carried out on leaves still attached to the trees. The trunk diameter of the sampled forest trees ranged from 10.2 to $101.9 \mathrm{~cm}$ (diameter at breast height, or $130 \mathrm{~cm}$ aboveground, DBH; Table S3). Excised branches were cut by a tree climber, and immediately recut under water to restore hydraulic conductivity (Domingues et al., 2010; Dusenge et al., 2015; Rowland et al., 2015).

\subsection{Photosynthetic light-response curves}

Photosynthetic light-response curves were measured on a total of 74 leaves from 23 different species, corresponding to 17 mature trees (13 species) and 12 saplings (4 species) at Paracou, and 4 pioneer trees ( 3 species) and 10 mature trees ( 8 species) at Nouragues (Table S1; Table S3). The trees were classified as climax or pioneer species based on local species knowledge (Bongers et al., 2001; Laurance et al., 2004; Molino \& Sabatier, 2001; Raaimakers et al., 1995). Measurements were performed at four different canopy heights, estimated relative to the top of the canopy: upper sunlit foliage, middle canopy foliage, lower canopy foliage, and branches of saplings ranging between 1 and $2 \mathrm{~m}$ height. For each species, sampling at two canopy heights was required to determine the height effect, and additional measurements on more canopy heights were carried out whenever possible to further strengthen the data analyses. Due to logistical constraints the measurements at Paracou were carried out at the end of the wet season 
and at Nouragues at the onset of the dry season, except for four pioneer trees that were measured during the wet season.

Light-response curves were established by measuring $A_{\mathrm{n}}$ at different PPFD levels, while maintaining a relatively constant chamber temperature. Leaves were first acclimated to 2000 $\mu \mathrm{mol} / \mathrm{m}^{2} / \mathrm{s}$ by exposing them to this PPFD level and waiting until $A_{\mathrm{n}}$ was stabilized. We subsequently decreased the PPFD in steps of $50-300 \mu \mathrm{mol} / \mathrm{m}^{2} / \mathrm{s}$ down to $0 \mu \mathrm{mol} / \mathrm{m}^{2} / \mathrm{s}$ to obtain a total of 14 and 11 measurements of $A_{\mathrm{n}}$ per leaf respectively for Nouragues and Paracou (PPFD levels in Nouragues: 2000-1800-1600-1400-1200-1000-800-600-400-200-100-50-25-0 $\mu \mathrm{mol} / \mathrm{m}^{2} / \mathrm{s}$, PPFD levels in Paracou: 2000-1800-1500-1000-800-600-400-200-100-50-0 $\left.\mu \mathrm{mol} / \mathrm{m}^{2} / \mathrm{s}\right)$. We considered the respiration measured at $0 \mu \mathrm{mol} / \mathrm{m}^{2} / \mathrm{s}$ to be an estimate of mitochondrial respiration in the light because there had not been sufficient time to completely relax respiration (Crous et al., 2012), but this is appropriate for light response curves. The $\mathrm{CO}_{2}$ concentration was kept constant at 400 ppm using an integrated gas mixing system and miniature $\mathrm{CO}_{2}$ cylinders.

\subsection{Photosynthetic $\mathrm{CO}_{2}$-response curves}

To obtain photosynthetic $\mathrm{CO}_{2}$-responses, we measured $A_{\mathrm{n}}$ at different $\mathrm{CO}_{2}$ concentrations by controlling the reference $\mathrm{CO}_{2}$ concentrations, starting at the ambient $\mathrm{CO}_{2}$ concentration of 400 ppm, but we maintained a constant temperature and PPFD level. The $\mathrm{CO}_{2}$ concentration was then first reduced stepwise to $50 \mathrm{ppm}$ (in steps of 50-100 ppm), then returned to $400 \mathrm{ppm}$ and thereafter increased to $2000 \mathrm{ppm}$ in steps of $200-300 \mathrm{ppm}$ to obtain a total of 14 measurements per leaf (reference $\mathrm{CO}_{2}$ concentrations: 400-300-200-100-50-400-400-600-800-1000-1200-15001700-2000). These $A_{\mathrm{n}}-C_{\mathrm{i}}$ curves (based on $C_{\mathrm{i}}$, the $\mathrm{CO}_{2}$ concentration of the leaf intercellular 
spaces) were measured on the upper sunlit foliage and lower canopy foliage for three trees (Table S2). Additional measurements were carried out on the middle canopy foliage for one of these trees and on four additional trees, resulting in a total of 14 curves on seven trees (six species) (Table S2). Response curves were made at a constant PPFD of 1300 and 1800 $\mu \mathrm{mol} / \mathrm{m}^{2} / \mathrm{s}$ consecutively, to study the effect of light intensity on the photosynthetic parameters $V_{\text {cmax }}\left(\mu \mathrm{mol} / \mathrm{m}^{2} / \mathrm{s}\right)$ and $J_{\max }\left(\mu \mathrm{mol} / \mathrm{m}^{2} / \mathrm{s}\right)($ Table S4). These parameters were derived by fitting the $A_{\mathrm{n}}-C_{\mathrm{i}}$ curves using the biochemical photosynthesis model of Farquhar, Von Caemmerer and Berry (Farquhar, Caemmerer, \& Berry, 1980) after temperature-correction (to $25^{\circ} \mathrm{C}$ ) using the equations and generalized kinetic coefficients from Sharkey, Bernacchi, Farquhar, and Singsaas (2007), without including the limitation by triose phosphate utilization. We assumed that mesophyll conductance was infinite.

\subsection{Data analysis}

Since maximum $A_{n}$ varied widely across species and canopy height classes, all individual light response curves were normalized by scaling the $A_{n}$ values between zero and one (Eq. 1) to examine relative declines in $A_{\mathrm{n}}$ with PPFD in all species.

$A_{n, \text { norm }}=\frac{A_{n}-\min \left(A_{n}\right)}{\max \left(A_{n}\right)-\min \left(A_{n}\right)}$

where $A_{n, n o r m}$ is the normalized value of $A_{\mathrm{n}}, A_{n}$ is the measured $A_{\mathrm{n}}$, and min and max are the minimum and maximum values of the measured $A_{\mathrm{n}}$ for each curve, respectively.

To test whether a common saturating PPFD level could be found over all canopy height levels, these normalized curves were averaged across species for each canopy height level, separating shade-tolerant climax species from light-demanding pioneer species (Bongers et al., 
2001). For each canopy height level, we determined the light saturation range, i.e. the PPFD range at which maximum $A_{\mathrm{n}}$ occurred. Starting from the highest observed $A_{n, \text { norm }}$, we employed two criteria that both needed to be met for adjacent PPFD levels to be included into this light saturation range. First, neighboring PPFD levels that did not significantly differ in $A_{\mathrm{n}, \mathrm{n} \text { rom }}$, based on their $95 \%$ confidence intervals, were also considered as light saturated. Second, the regression slope between the measured $A_{\mathrm{n}, \mathrm{norm}}$ values considered at light saturation could not differ from zero.

We compared the obtained light saturation ranges for all measured leaves at all canopy heights and searched for a PPFD level that occurred in all light saturation ranges, which we coined the common saturating PPFD level. To test whether $A_{n}$ at this common saturating PPFD level differed from an estimated $A_{n}$ at $2000 \mu \mathrm{mol} / \mathrm{m}^{2} / \mathrm{s}$ under the assumption that no photoinhibition occurred, we then fitted a nonrectangular hyperbola based model (Eq. 2; (Lobo et al., 2013)) to the measured $A_{n}$-PPFD curves and calculated $A_{n}$ at this common saturating PPFD level. We tested whether this value was within five percent of $A_{\text {sat,mod, }}$, defined as the modelled $A_{n}$ value at a PPFD of $2000 \mu \mathrm{mol} / \mathrm{m}^{2} / \mathrm{s}$. Hence, if for example $A_{n}$ at the common saturating PPFD is greater than $A_{\text {sat,mod }}\left( \pm 5 \%\right.$ ), this is taken to suggest photoinhibition at a PPFD of $2000 \mu \mathrm{mol} / \mathrm{m}^{2} / \mathrm{s}$. To test for interspecific differences and differences among canopy heights in the PPFD level at which $A_{n}$ becomes saturated, we tested the effects of species and canopy height level on the residuals of $A_{\text {sat }}$, measured at the common saturating PPFD, and $A_{\text {sat,mod, }}$, using a linear mixed model (nlme package (Pinheiro, Bates, Debroy, Sarkar, \& R Core Team, 2020)) with canopy height level as fixed factor and species as random factor. Note that these analyses were done only for the climax species, not for the pioneer species, because for the latter $A_{n}$ did not saturate within the light range used in this study. 
$A_{n}=\frac{\phi * P P F D+A_{\text {gmax }}-\sqrt{\left(\phi * P P F D+A_{\text {gmax }}\right)^{2}-4 * \phi * \theta * A_{\operatorname{gmax}} * P P F D}}{2 * \theta}-R_{d}$

where $A_{n}$ is the net photosynthetic rate $\left(\mu \mathrm{mol}\left(\mathrm{CO}_{2}\right) / \mathrm{m}^{2} / \mathrm{s}\right) ; \varphi$ is the apparent quantum yield at $\mathrm{PPFD}=0\left(\mu \mathrm{mol}\left(\mathrm{CO}_{2}\right) / \mu \mathrm{mol}\right.$ (photon) $)$ PPFD is the photosynthetic photon flux density $(\mu \mathrm{mol}$ (photon) $\left./ \mathrm{m}^{2} / \mathrm{s}\right) ; A_{\text {gmax }}$ is the asymptotic estimate of the maximum gross photosynthetic rate $(\mu \mathrm{mol}$ $\left.\left(\mathrm{CO}_{2}\right) / \mathrm{m}^{2} / \mathrm{s}\right) ; \theta$ (dimensionless) indicates the convexity.

Stomatal closure induced by water limitation could have occurred at the highest PPFD levels and could therefore contribute to the observed decline in $A_{n}$ above light saturation. We therefore tested whether the stomatal conductance measured at a PPFD of $2000 \mu \mathrm{mol} / \mathrm{m}^{2} / \mathrm{s} \mathrm{differed} \mathrm{from}$ the stomatal conductance measured at the common saturating PPFD level obtained in this study. Since normality assumptions were not met, a paired Wilcoxon signed-rank test was performed to test if the stomatal conductance at and above light saturation was significantly different.

We calculated the ratio of $J_{\max , 1300}: J_{\max , 1800}$ and $V_{c \max , 1300}: V_{c \max , 1800, \text { measured at a PPFD }}$ of $1300 \mu \mathrm{mol} / \mathrm{m}^{2} / \mathrm{s}$ and $1800 \mu \mathrm{mol} / \mathrm{m}^{2} / \mathrm{s}$ respectively, to test for an effect of PPFD on $J_{\max }$ and $V_{\text {cmax. }}$ These ratios were calculated as the slope estimates of the linear regression by 10,000 bootstrap replicates. Both PPFD levels were assumed to be at light saturation if the ratio did not differ significantly from 1 , based on the $95 \%$ confidence intervals corresponding to 2.5 and 97.5\% quantiles after bootstrapping. Bootstrapping involves resampling with replacement from the original data to simulate multiple samples from a population (Chernick \& LaBudde, 2011). Additionally, we performed a paired t-test to test whether $J_{\max }$ and $V_{\text {cmax }}$ differed between a PPFD of $1300 \mu \mathrm{mol} / \mathrm{m}^{2} / \mathrm{s}$ and $1800 \mu \mathrm{mol} / \mathrm{m}^{2} / \mathrm{s}$. We tested if the $J_{\text {max }}: V_{\text {cmax }}$ ratio differed between 1300 and $1800 \mu \mathrm{mol} / \mathrm{m}^{2} / \mathrm{s}$ with a linear regression with the ratio as the dependent variable and 
the PPFD level as fixed factor. All analyses were performed in R 3.3.3 (R Core Team, 2017) using the ggplot2 package (Wickham, 2009) for visualization of the data.

\section{RESULTS}

For upper canopy sunlit leaves, the light saturation point was reached at ca. $1000 \mu \mathrm{mol} / \mathrm{m}^{2} / \mathrm{s}$ (Figure 1a,d). In Nouragues, $A_{\mathrm{n}, \text { norm }}$ did not change between 1000 and $1600 \mu \mathrm{mol} / \mathrm{m}^{2} / \mathrm{s}$, but decreased statistically significantly $\left(F_{1,91}=4.69 ; P=0.03\right)$ at higher PPFD $(2.4 \%$ decrease from 1600 to $2000 \mu \mathrm{mol} / \mathrm{m}^{2} / \mathrm{s}$, Figure 1a). This decrease in $A_{\mathrm{n}, \mathrm{norm}}$ at $2000 \mu \mathrm{mol} / \mathrm{m}^{2} / \mathrm{s}$ was not apparent at the Paracou site (Figure 1d), where $A_{\mathrm{n}, \text { norm }}$ did not significantly differ between 1000 and 2000 $\mu \mathrm{mol} / \mathrm{m}^{2} / \mathrm{s}$.

Compared to the upper canopy sunlit leaves, leaves within the canopy (e.g. 'lower' and 'middle' canopy) saturated at lower PPFD. At Nouragues, the light saturation point of these midcanopy leaves was reached at $800 \mu \mathrm{mol} / \mathrm{m}^{2} / \mathrm{s}$ and $A_{\mathrm{n}, \text { norm }}$ did not change between 800 and 1400 $\mu \mathrm{mol} / \mathrm{m}^{2} / \mathrm{s}$ (Figure 1e). This light-saturating PPFD range was similar for both the middle and lower canopy foliage (Figure 1b,c). At Paracou, in the lower canopy stratum, the light saturation point was reached at $800 \mu \mathrm{mol} / \mathrm{m}^{2} / \mathrm{s}$, and $A_{\mathrm{n}, \text { norm }}$ did not vary significantly between 800 and 1800 $\mu \mathrm{mol} / \mathrm{m}^{2} / \mathrm{s}$ (Figure 1e). For saplings, the light saturation range was smaller and light saturation occurred between 800 and $1000 \mu \mathrm{mol} / \mathrm{m}^{2} / \mathrm{s}$ (Figure 1f). In strong contrast with the leaves of

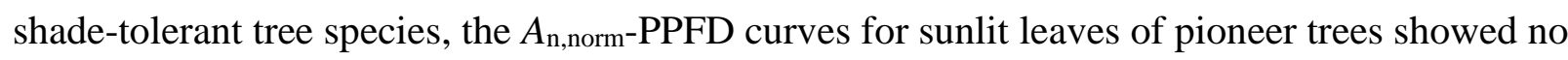
signs of saturation of $A_{\mathrm{n}, \mathrm{norm}}$ within the investigated PPFD range (0 to $2000 \mu \mathrm{mol} / \mathrm{m}^{2} / \mathrm{s}$, Figure 2 ).

Aside from the pioneer species, light saturation was reached within a PPFD range that varied per canopy height, with $1000 \mu \mathrm{mol} / \mathrm{m}^{2} / \mathrm{s}$ as common saturating PPFD level. 73 percent of 
the $A_{\text {sat, } 1000}(\mathrm{n}=50)$, the $A_{\text {sat }}$ measured at $1000 \mu \mathrm{mol} / \mathrm{m}^{2} / \mathrm{s}$, was within five percent of $A_{\text {sat,2000, }}$ defined as the modelled $A_{\text {sat }}$ value at a PPFD of $2000 \mu \mathrm{mol} / \mathrm{m}^{2} / \mathrm{s}$ (Figure 3), while ten percent of $A_{\text {sat }, 1000}(\mathrm{n}=7)$ was above $A_{\text {sat }, 2000}+5 \%$ and 17 percent $(\mathrm{n}=12)$ below $A_{\text {sat }, 2000}-5 \%$. Canopy height level (likelihood ratio $=3.33 ; P=0.19$ ) had no significant effect on deviations of the residuals of $A_{s a t, 1000}$ and $A_{s a t, 2000}$ for climax species. The variance of the tree species only accounted for less than one percent of the total variance, with a random intercept of 3.96E-06.

The stomatal conductance at a PPFD of $2000 \mu \mathrm{mol} / \mathrm{m}^{2} / \mathrm{s}$ differed significantly from the stomatal conductance measured at the common saturating PPFD level of $1000 \mu \mathrm{mol} / \mathrm{m}^{2} / \mathrm{s}$ (Wilcoxon paired test, $V=533 ; P<0.001$; Figure 4). The stomatal conductance at a PPFD of $2000 \mu \mathrm{mol} / \mathrm{m}^{2} / \mathrm{s}$ was higher than at a PPFD of $1000 \mu \mathrm{mol} / \mathrm{m}^{2} / \mathrm{s}$.

Across all species and heights in the canopy, the photosynthetic parameters $J_{\max }$ and $V_{\mathrm{cmax}}$ did not significantly differ between the light intensities of 1300 and $1800 \mu \mathrm{mol} / \mathrm{m}^{2} / \mathrm{s}$. When treating the data in a paired way, there is no significant difference for $J_{\max }\left(t_{13}=1.70 ; P=0.11\right)$ and $V_{\text {cmax }}\left(t_{13}=1.31 ; P=0.21\right)$ between these parameters measured at a PPFD of 1300 and 1800 $\mu \mathrm{mol} / \mathrm{m}^{2} / \mathrm{s}$. After bootstrapping the data, the ratio of $\mathrm{J}_{\max , 1300}: \mathrm{J}_{\max , 1800}$ and $\mathrm{V}_{\mathrm{cmax}, 1300}: \mathrm{V}_{\mathrm{cmax}, 1800}$ were $1.08 \pm 0.07 \mu \mathrm{mol} / \mathrm{m}^{2} / \mathrm{s}$ and $0.97 \pm 0.30 \mu \mathrm{mol} / \mathrm{m}^{2} / \mathrm{s}$, respectively. The $95 \%$ confidence interval for both $J_{\max }([0.92 ; 1.17])$ and $V_{c \max }([0.27 ; 1.32])$ included one and thus the ratio did not differ significantly from one. The mean ratio $\mathrm{J}_{\max , 1300}: \mathrm{V}_{\mathrm{cmax}, 1300}(1.54)$ was not significantly different from the mean ratio $\mathrm{J}_{\max , 1800}: \mathrm{V}_{\mathrm{cmax}, 1800}(1.71)\left(F_{1,26}=1.03 ; P=0.32\right)$.

\section{DISCUSSION}

A common PPFD level at which leaf-level photosynthesis saturates in lowland tropical forests would facilitate the comparison between different tree species and height levels within the 
canopy, and between different study sites and studies. Our data suggest that at our study sites in French Guiana, dominated by shade-tolerant tree species growing on infertile soils (Grau et al., 2017; Hammond, 2005; ter Steege et al., 2013), $A_{\text {sat }}$ can best be measured within a PPFD range of 1000 to $1400 \mu \mathrm{mol} / \mathrm{m}^{2} / \mathrm{s}$ for canopy trees, while saplings showed saturation at lower light conditions, within a range of 800 to $1000 \mu \mathrm{mol} / \mathrm{m}^{2} / \mathrm{s}$, since they are acclimated to a low PPFD regime. Saplings in tropical forests typically receive less than two percent of the incoming light at the top of the canopyv(Montgomery \& Chazdon, 2002; Théry, 2001; Yoda, 1974). For climax canopy trees, $A_{\text {sat }}$ can thus be measured within a wide PPFD range, with a common PPFD of $1000 \mu \mathrm{mol} / \mathrm{m}^{2} / \mathrm{s}$ throughout the whole canopy (Figure 1).

It must, however, be clearly stated that the above does not hold for the pioneer species investigated in this study. None of the seven measured pioneer trees belonging to the Cecropiaceae family included in this study showed signs of saturation up to a PPFD of 2000 $\mu \mathrm{mol} / \mathrm{m}^{2} / \mathrm{s}$ (Figure 2) - the maximum light intensity that could be reached with our device. Pioneer trees typically have higher light saturation points compared to climax trees (Chazdon, Pearcy, Lee, \& Fetcher, 1996; Lüttge, 2008; Silvestrini, Válio, \& Mattos, 2007), which is supported by this study. Measuring leaf-level photosynthesis of pioneer trees at the light saturation range established in this study, or even at PPFD of $2000 \mu \mathrm{mol} / \mathrm{m}^{2} / \mathrm{s}$ is thus likely to underestimate $A_{\text {sat }}$, and generalization beyond the Cecropiaceae family requires further study. Hence, studies seeking to compare photosynthetic traits in early-successional habitats or pioneer species with late-successional species need to evaluate traits such as $A_{s a t}, V_{c \max }$ and $J_{\max }$ for different, saturating PPFD levels appropriate to their successional status.

We hypothesized that photosynthesis becomes light saturated at lower PPFD levels when leaves are more shade-adapted. In accordance with this hypothesis, the light saturation range 
measured in this study started at lower PPFD levels and became more narrow for leaves positioned deeper in the canopy (i.e. more shade-adapted leaves). Nonetheless, this saturation range of shade-adapted leaves overlapped with the saturation range of sun-adapted leaves at the top of the canopy. At the Nouragues site, the upper boundary of the light saturation range decreased vertically from the top of the canopy $\left(1600 \mu \mathrm{mol} / \mathrm{m}^{2} / \mathrm{s}\right)$ to the forest floor $(1400$ $\mu \mathrm{mol} / \mathrm{m}^{2} / \mathrm{s}$ ). Opposed to results from previous studies (e.g. Ellsworth and Reich (1993)), we did not find a continuous decrease in light saturation point towards the lower canopy, as the middle and lower canopy foliage at the Nouragues site showed the same light saturation point range (800 to $1400 \mu \mathrm{mol} / \mathrm{m}^{2} / \mathrm{s}$ ). At Paracou, the light saturation range of the lower canopy foliage (800 $\left.-1800 \mu \mathrm{mol} / \mathrm{m}^{2} / \mathrm{s}\right)$ was slightly lower than that of the upper canopy sunlit leaves $(1000-2000$ $\mu \mathrm{mol} / \mathrm{m}^{2} / \mathrm{s}$ ), and the lower boundary overlapped with the range of the saplings in the understory.

We hypothesized that at high PPFD (above saturation for photosynthesis), photoinhibition would occur at all heights in the canopy, but that this reduction in leaf-level photosynthesis would be more pronounced lower in the canopy where leaves are not used to receiving high light intensities. At the Nouragues site, upper sunlit canopy foliage exhibited a statistically significant decline in $A_{\mathrm{n}, \mathrm{norm}}$ measured at a PPFD of $2000 \mu \mathrm{mol} / \mathrm{m}^{2} / \mathrm{s}$, which was not caused by stomatal closure based on available evidence (Figure 4; Figure S1; Figure S2). However, this decline was only minor in magnitude (2\%) and did not occur at the other canopy heights, nor was it found for sunlit leaves at the Paracou site. We thus refute the hypothesis of a pronounced decline in $A_{\mathrm{n}}$ measured at a PPFD of $2000 \mu \mathrm{mol} / \mathrm{m}^{2} / \mathrm{s}$ for more shade-adapted leaves, although it is obviously more advisable to measure $A_{\text {sat }}$ at lower PPFD for all but pioneer tree leaves. 
Total incoming light at the top of the canopy in tropical forests can exceed 2000 $\mu \mathrm{mol} / \mathrm{m}^{2} / \mathrm{s}$ (Shuttleworth, 1984), and we therefore expected that the light saturation point of the upper canopy sunlit leaves would be reached at PPFD levels close to $2000 \mu \mathrm{mol} / \mathrm{m}^{2} / \mathrm{s}$ for optimal light use efficiency. However, the upper canopy sunlit leaves typically received much less incoming PPFD due to the diel cycle of the solar zenith angle and the leaf angle (VentreLespiaucq, Flanagan, Ospina-Calderon, Delgado, \& Escudero, 2018). This is demonstrated by the comparison of light interception by sensors installed on the leaves themselves compared to measurements of incoming light on the flux tower (Figure S3), indicating that the leaves are not frequently exposed to very high PPFD levels. Trees are able to adjust the spatial configuration of their leaves by changing the leaf angle or orientation to control their light interception and energy balance, e.g. reorient a leaf blade parallel to the sun rays to intercept less PPFD and avoid excessive light (Posada, Lechowicz, \& Kitajima, 2009). Increasing the frequency of low/medium PPFD incident on leaves can increase photosynthetic light use efficiency (Posada et al., 2012), but can also reduce photoinhibition and stress associated with high irradiance (Posada et al., 2009; Walters \& Field, 1987) and warming (Doughty, 2011; Slot \& Winter, 2017). This is an important characteristic, especially for sunlit leaves of canopy dominant trees that are frequently exposed to high PPFD levels and risk experiencing high-radiation damage. Due to their leaf angle not being perpendicular to the solar beams, sunlit leaves thus typically intercept less light than is incoming at the top of the canopy and we postulate that this is the reason why the light saturation point occurred at much lower PPFD levels than the typical incoming light intensity at the top of the canopy.

We further tested whether $V_{\text {cmax }}$ and $J_{\max }$ differed between PPFD levels of 1300 and 1800 $\mu \mathrm{mol} / \mathrm{m}^{2} / \mathrm{s}$. Assuming that the PPFD of $1800 \mu \mathrm{mol} / \mathrm{m}^{2} / \mathrm{s}$ does not induce photoinhibition, $A_{\mathrm{n}}$ is 
light saturated at this PPFD level (as reported in e.g. Weerasinghe et al. (2014) and Bahar et al. (2016)), and thus maximum values for $V_{\mathrm{cmax}}$ and $J_{\max }$ are reached. Below light saturation, $A_{\mathrm{n}}$ is usually considered to become limited by rates of photosynthetic electron transport $\left(J_{\max }\right)$ (Farquhar et al., 1980). Hence, measuring $A_{\mathrm{n}}-C_{\mathrm{i}}$ curves below light saturation is more likely to lead to underestimation of $J_{\max }$ (Buckley \& Diaz-Espejo, 2015), than of $V_{\text {cmax }}$. The lack of difference between $V_{\text {cmax,1300 }}$ and $V_{\text {cmax,1800 }}$ was thus expected and was even hypothesized by Buckley and Diaz-Espejo (2015). In contrast, $J_{\max }$ is derived from the light limited part of the curve and a higher $J_{\max }$ at a PPFD of $1800 \mu \mathrm{mol} / \mathrm{m}^{2} / \mathrm{s}$ than at $1300 \mu \mathrm{mol} / \mathrm{m}^{2} / \mathrm{s}$ would be expected if light was not saturating at $1300 \mu \mathrm{mol} / \mathrm{m}^{2} / \mathrm{s}$, because this term of the Farquhar-von CaemmererBerry (1980) photosynthesis model is light sensitive below light saturation. However, $J_{\max }$ did not significantly differ between a PPFD of 1300 and $1800 \mu \mathrm{mol} / \mathrm{m}^{2} / \mathrm{s}$, which is in accordance with the light saturation range established for $A_{\text {sat }}$ and confirms that the PPFD of $1300 \mu \mathrm{mol} / \mathrm{m}^{2} / \mathrm{s}$ was at light saturation. Although the ratio $J_{\max }: V_{c \max }$ in this study was in the lower range of what was found in other studies (e.g. Bahar et al. (2016); Rowland et al. (2015)), the ratio $J_{\max }: V_{c \max }$ did not differ significantly between PPFD levels of 1300 and $1800 \mu \mathrm{mol} / \mathrm{m}^{2} / \mathrm{s}$, confirming light saturation at both PPFD levels and no photoinhibition at $1800 \mu \mathrm{mol} / \mathrm{m}^{2} / \mathrm{s}$.

Overall, $A_{\mathrm{n}}$ was light-saturated over a wide range of PPFD levels, but for all tree species and on all heights within the adult tree canopy $A_{\mathrm{n}}$ reached saturation at $1000 \mu \mathrm{mol} / \mathrm{m}^{2} / \mathrm{s}$. The exception to this generalization were the pioneer trees, which did not reach light saturation even at light levels up to $2000 \mu \mathrm{mol} / \mathrm{m}^{2} / \mathrm{s}$. These results suggest that a light intensity of 1000 $\mu \mathrm{mol} / \mathrm{m}^{2} / \mathrm{s}$ is sufficient for measuring $A_{\text {sat }}$ of climax species in the lowland forests of French Guiana, no matter at which canopy height the measurements are taken. Moreover, the negligible magnitude of photoinhibition (if at all present) in our study implies that any value of PPFD 
within the range of $1000-2000 \mu \mathrm{mol} / \mathrm{m}^{2} / \mathrm{s}$ would have yielded accurate values of $A_{\text {sat }}$. This study thus clearly shows that, with exception of pioneer species belonging to the Cecropiaceae family, tropical tree photosynthesis data reported in previous studies can quite safely be compared even if different PPFD levels were used, given that a minimum of $1000 \mu \mathrm{mol} / \mathrm{m}^{2} / \mathrm{s}$ PPFD was provided for canopy leaves. Some caution is warranted since this study took place in the nutrient poor forests of French Guiana, and different light, water and nutrient environments of tropical forests and different species composition might have the potential to change the light saturation range. 


\section{ACKNOWLEDGEMENTS}

L. T. Verryckt is funded by a PhD fellowship from the Research Foundation Flanders (FWO). I. A. Janssens acknowledges support from the European Research Council Synergy Grant; ERC2013-SyG-610028 IMBALANCE-P. We thank the staff of the Nouragues Natural Reserve and The Nouragues Ecological Research Station, supported by USR mixte LEEISA (CNRS; Cayenne, French Guiana). The research station has benefited from financial support by French Investissement d'Avenir programs managed by the ANR (AnaEE-France ANR-11-INBS-0001; Labex CEBA ANR-10-LABX-25-01).

We are grateful to Stefan van Beveren, Valentine Alt, Jean-Loup Touchard, Anthony Percevaux, and Samuel Counil for climbing the trees to collect the selected branches. We thank the rest of the team for helping us with the field measurements.

\section{CONFLICT OF INTEREST}

The corresponding author confirms on behalf of all authors that there have been no involvements that might raise the question of bias in the work reported or in the conclusions, implications, or opinions stated.

\section{DATA AVAILABILITY STATEMENT}

The data that support the findings of this study are openly available in Dryad Digital Repository at https://doi.org/10.5061/dryad.5hqbzkh39. 


\section{LITERATURE CITED}

Bahar, N. H., Ishida, F. Y., Weerasinghe, L. K., Guerrieri, R., O'Sullivan, O. S., Bloomfield, K. J., . . Atkin, O. K. (2016). Leaf-level photosynthetic capacity in lowland Amazonian and high-elevation Andean tropical moist forests of Peru. New Phytologist, 214(3), 1002-1018. doi:10.1111/nph.14079

Beer, C., Reichstein, M., Tomelleri, E., Ciais, P., Jung, M., Carvalhais, N., . . Papale, D. (2010). Terrestrial Gross Carbon Dioxide Uptake - global distribution and variation with climate. Science, 329(5993), 834-838. doi:10.1126/science.1184984

Bonal, D., Bosc, A., Ponton, S., Goret, J.-Y., Burban, B., Gross, P., . . Granier, A. (2008). Impact of severe dry season on net ecosystem exchange in the Neotropical rainforest of French Guiana. Global Change Biology, 14(8), 1917-1933. doi:10.1111/j.13652486.2008.01610.x

Bongers, F., Charles-Dominique, P., Forget, P.-M., \& Théry, M. (2001). Nouragues: Dynamics and Plant-Animal Interactions in a Neotropical Rainforest. Dordrecht, The Netherlands: Kluwer Academic Publishers.

Buckley, T. N., \& Diaz-Espejo, A. (2015). Reporting estimates of maximum potential electron transport rate. New Phytologist, 205, 14-17. doi:10.1111/nph.13018

Cavaleri, M. A., Reed, S. C., Smith, W. K., \& Wood, T. E. (2015). Urgent need for warming experiments in tropical forests. Global Change Biology, 21, 2111-2121. doi: $10.1111 / \mathrm{gcb} .12860$

Chazdon, R. L., Pearcy, R. W., Lee, D. W., \& Fetcher, N. (1996). Tropical forest plant ecophysiology (S. S. Mulkey, R. L. Chazdon, \& A. P. Smith Eds.). New York: Chapman \& Hall. 
Chernick, M. R., \& LaBudde, R. A. (2011). An introduction to bootstrap methods with applications to $R$.

Clark, D. A., Asao, S., Fisher, R., Reed, S., Reich, P. B., Ryan, M. G., . . . Yang, X. (2017). Reviews and syntheses: Field data to benchmark the carbon cycle models for tropical forests. Biogeosciences, 14(20), 4663-4690. doi:10.5194/bg-14-4663-2017

Crous, K. Y., Zaragoza-Castells, J., Ellsworth, D. S., Duursma, R. A., Low, M., Tissue, D. T., \& Atkin, O. K. (2012). Light inhibition of leaf respiration in field-grown Eucalyptus saligna in whole-tree chambers under elevated atmospheric $\mathrm{CO} 2$ and summer drought. Plant, Cell and Environment, 35(5), 966-981. doi:10.1111/j.1365-3040.2011.02465.x

De Kauwe, M. G., Lin, Y. S., Wright, I. J., Medlyn, B. E., Crous, K. Y., Ellsworth, D. S., . . . Domingues, T. F. (2016). A test of the 'one-point method' for estimating maximum carboxylation capacity from field-measured, light-saturated photosynthesis. New Phytologist, 210(3), 1130-1144. doi:10.1111/nph.13815

Demmig-Adams, B., \& Adams III, W. W. (1992). Photoprotection and other responses of plants to high light stress. Annual Review of Plant Physiology and Plant Molecular Biology, 43, 599-626. doi:10.1146/annurev.pp.43.060192.003123

Denslow, J. S. (1987). Tropical rainforest gaps and tree species diversity. Annual Review of Ecology and Systematics, 18, 431-451. doi:10.1146/annurev.es.18.110187.002243

Domingues, T. F., Martinelli, L. A., \& Ehleringer, J. R. (2014). Seasonal patterns of leaf-level photosynthetic gas exchange in an eastern Amazonian rain forest. Plant Ecology \& Diversity, 7, 189-203. doi:10.1080/17550874.2012.748849

Domingues, T. F., Meir, P., Feldpausch, T. R., Saiz, G., Veenendaal, E. M., Schrodt, F., .. Lloyd, J. (2010). Co-limitation of photosynthetic capacity by nitrogen and phosphorus in West 
Africa woodlands. Plant, Cell and Environment, 33, 959-980. doi:10.1111/j.13653040.2010.02119.x

Doughty, C. E. (2011). An in situ leaf and branch warming experiment in the Amazon. Biotropica, 43(6), 658-665. doi:10.1111/j.1744-7429.2010.00746.x

Doughty, C. E., Metcalfe, D. B., Girardin, C. A. J., Farfán Amézquita, F., Cabrera, D. G., Huarca Huasco, W., . . Malhi, Y. (2015). Drought impact on forest carbon dynamics and fluxes in Amazonia. Nature, 519(7541), 78-82. doi:10.1038/nature14213

Dusenge, M. E., Walling, G., Gårdesten, J., Nyronzima, F., Adolfsson, L., Nsabimana, D., \& Uddling, J. (2015). Photosynthetic capacity of tropical montane tree species in relation to leaf nutrients, successional strategy and growth temperature. Oecologia, 117, 1183-1194. doi:10.1007/s00442-015-3260-3

Ellsworth, D. S., \& Reich, P. B. (1993). Canopy structure and vertical patterns of photosynthesis and related leaf traits in a deciduous forest. Oecologia, 96, 169-178. doi:10.1007/BF00317729

FAO. (1998). World reference base for soil resources. World Soil Resources Report No. 84. Rome: ISSS-ISRIC-FAO.

Farquhar, G. D., Caemmerer, S., \& Berry, J. A. (1980). A biochemical model of photosynthetic CO2 assimilation in leaves of C3 species. Planta, 149(1), 78-90. doi:10.1007/BF00386231

Fine, P. V. A., Ree, R. H., \& Burnham, R. J. (2008). The disparity in tree species richness among tropical, temperate, and boreal biomes: the geographical area and age hypothesis. In R. P. Carson \& S. A. Schnitzer (Eds.), Tropical Forest Community Ecology (pp. 31-45). Oxford, UK: Blackwell. 
Fisher, J. B., Huntzinger, D. N., Schwalm, C. R., \& Sitch, S. (2014). Modeling the Terrestrial Biosphere. Annual Review of Environment and Resources, 39(1), 91-123. doi:10.1146/annurev-environ-012913-093456

Gentry, A. H. (1982). Patterns of Neotropical Plant Species Diversity. In M. K. Hecht, B. Wallace, \& G. T. Prance (Eds.), Evolutionary Biology: Volume 15 (pp. 1-84). Boston, MA: Springer US.

Goldstein, G., \& Santiago, L. S. (2016). Tropical Tree Physiology - Adaptations and Responses in a Changing Environment (Vol. 6). Switzerland: Springer International Publishing.

Grau, O., Peñuelas, J., Ferry, B., Freycon, V., Blanc, L., Desprez, M., . . . Hérault, B. (2017). Nutrient-cycling mechanisms other than the direct absorption from soil may control forest structure and dynamics in poor Amazonian soils. Scientific Reports, 7, 45017. doi:10.1038/srep45017

Hammond, D. S. (2005). Tropical Forests of the Guiana Shield: Ancient Forests in a Modern World (D. S. Hammond Ed.). Wallingford, Oxfordshire, UK: CABI Publishing.

Iida, Y., Poorter, L., Sterck, F., Rahman Kassim, A., Potts, M. D., Kubo, T., \& Kohyama, T. S. (2014). Linking size-dependent growth and mortality with architectural traits across 145 co-occurring tropical tree species. Ecology, 95(2), 353-363. doi:10.1890/11-2173.1

Kattge, J., Díaz, S., Lavorel, S., Prentice, I. C., Leadley, P., Bönisch, G., . . W Wirth, C. (2011). TRY - a global database of plant traits. Global Change Biology, 17(9), 2905-2935. doi:10.1111/j.1365-2486.2011.02451.x

Kattge, J., Knorr, W., Raddatz, T., \& Wirth, C. (2009). Quantifying photosynthetic capacity and its relationship to leaf nitrogen content for global-scale terrestrial biosphere models. Global Change Biology, 15(4), 976-991. doi:10.1111/j.1365-2486.2008.01744.x 
Kitajima, K. (1994). Relative Importance of Photosynthetic Traits and Allocation Patterns as Correlates of Seedling Shade Tolerance of 13 Tropical Trees. Oecologia, 98(3-4), 419-428. doi:10.1007/Bf00324232

Laurance, W. F., Nascimento, H. E. M., Laurance, S. G., Condit, R., D’Angelo, S., \& Andrade, A. (2004). Inferred longevity of Amazonian rainforest trees based on a long-term demographic study. Forest Ecology and Management, 190(2-3), 131-143. doi:10.1016/j.foreco.2003.09.011

Lewis, J. D., McKane, R. B., Tingey, D. T., \& Beedlow, P. A. (2000). Vertical gradients in photosynthetic light response within an old-growth Douglas-fir and western hemlock canopy. Tree Physiology, 20, 447-456. doi:10.1093/treephys/20.7.447

Lobo, F. d. A., de Barros, M. P., Dalmagro, H. J., Dalmolin, Â. C., Pereira, W. E., de Souza, É. C., . . Rodríguez Ortíz, C. E. (2013). Fitting net photosynthetic light-response curves with Microsoft Excel — a critical look at the models. Photosynthetica, 51(3), 445-456. doi:10.1007/s11099-013-0045-y

Long, S. P., Humphries, S., \& Falkowski, P. G. (1994). Photoinhibition of photosynthesis in nature. Annual Review of Plant Physiology and Plant Molecular Biology, 45, 633-662. doi:10.1146/annurev.pp.45.060194.003221

Lüttge, U. (2008). Physiological ecology of tropical plants: Springer-Verlag Berlin Heidelberg. Malhi, Y. (2010). The carbon balance of tropical forest regions, 1990-2005. Current Opinion in Environmental Sustainability, 2(4), 237-244. doi:10.1016/j.cosust.2010.08.002

Markesteijn, L., Poorter, L., \& Bongers, F. (2007). Light-dependent leaf trait variation in 43 tropical dry forest tree species. American Journal of Botany, 94(4), 515-525. doi:10.3732/ajb.94.4.515 
Martinez-Camilo, R., Gonzalez-Espinosa, M., Ramirez-Marcial, N., Cayuela, L., \& Perez-Farrera, M. A. (2017). Tropical tree species diversity in a mountain system in southern Mexico: local and regional patterns and determinant factors. Biotropica, 50(3), 499-509. doi:10.1111/btp.1253

Molino, J.-F., \& Sabatier, D. (2001). Tree Diversity in Tropical Rain Forests: A Validation of the Intermediate Disturbance Hypothesis. Science, 294(5547), 1702-1704. doi:10.1126/science.1060284

Montgomery, R., \& Chazdon, R. (2002). Light gradient partitioning by tropical tree seedlings in the absence of canopy gaps. Oecologia, 131(2), 165-174. doi:10.1007/s00442-002-0872-1

Niinemets, Ü. (2007). Photosynthesis and resource distribution through plant canopies. Plant, Cell and Environment, 30(9), 1052-1071. doi:10.1111/j.1365-3040.2007.01683.x

Niinemets, Ü., Keenan, T. F., \& Hallik, L. (2015). A worldwide analysis of within-canopy variations in leaf structural, chemical and physiological traits across plant functional types. New Phytologist, 205(3), 973-993. doi:10.1111/nph.13096

Parra, M. J., Acuna, K. I., Sierra-Almeida, A., Sanfuentes, C., Saldana, A., Corcuera, L. J., \& Bravo, L. A. (2015). Photosynthetic Light Responses May Explain Vertical Distribution of Hymenophyllaceae Species in a Temperate Rainforest of Southern Chile. PLoS One, 10(12), e0145475. doi:10.1371/journal.pone.0145475

Pinheiro, J., Bates, D., Debroy, S., Sarkar, D., \& R Core Team. (2020). nlme: Linear and nonlinear mixed effects models.

Posada, J. M., Lechowicz, M. J., \& Kitajima, K. (2009). Optimal photosynthetic use of light by tropical tree crowns achieved by adjustment of individual leaf angles and nitrogen content. Annals of Botany, 103(5), 795-805. doi:10.1093/aob/mcn265 
Posada, J. M., Sievanen, R., Messier, C., Perttunen, J., Nikinmaa, E., \& Lechowicz, M. J. (2012). Contributions of leaf photosynthetic capacity, leaf angle and self-shading to the maximization of net photosynthesis in Acer saccharum: a modelling assessment. Annals of Botany, 110(3), 731-741. doi:10.1093/aob/mcs106

Powles, S. B. (1984). Photoinhibition of photosynthesis induced by visible light. Annual Review of Plant Physiology, 35, 15-44. doi:10.1146/annurev.pp.35.060184.000311

R Core Team. (2017). R: A Language and Environment for Statistical Computing. Vienna, Austria: R Foundation for Statistical Computing.

Raaimakers, D., Boot, R. G. A., \& Dijkstra, P. (1995). Photosynthetic rates in relation to leaf phosphorus content in pioneer versus climax tropical rainforest trees. Oecologia, 102, 120125. doi:10.1007/BF00333319

Reich, P. B., Walters, M. B., \& Ellsworth, D. S. (1997). From tropics to tundra: global convergence in plant functioning. Proceedings of the National Academy of Sciences of the United States of America, 94(25), 13730-13734. doi:10.1073/pnas.94.25.13730

Rijkers, T., Pons, T. L., \& Bongers, F. (2000). The effect of tree height and light availability on photosynthetic leaf traits of four neotropical species differing in shade tolerance. Functional Ecology, 14(1), 77-86. doi:10.1046/j.1365-2435.2000.00395.x

Rogers, A., Medlyn, B. E., Dukes, J. S., Bonan, G., Caemmerer, S., Dietze, M. C., . . Zaehle, S. (2017). A roadmap for improving the representation of photosynthesis in Earth system models. New Phytologist, 213(1), 22-42. doi:10.1111/nph.14283

Rowland, L., Lobo-do-Vale, R. L., Christoffersen, B. O., Melem, E. A., Kruijt, B., Vasconcelos, S. S., . . . Meir, P. (2015). After more than a decade of soil moisture deficit, tropical 
rainforest trees maintain photosynthetic capacity, despite increased leaf respiration. Global Change Biology, 21(12), 4662-4672. doi:10.1111/gcb.13035

Rowland, L., Zaragoza-Castells, J., Bloomfield, K. J., Turnbull, M. H., Bonal, D., Burban, B., . . Meir, P. (2016). Scaling leaf respiration with nitrogen and phosphorus in tropical forests across two continents. New Phytologist, 214(3), 1064-1077. doi:10.1111/nph.13992

Santos, V. A. H. F. D., Ferreira, M. J., Rodrigues, J. V. F. C., Garcia, M. N., Ceron, J. V. B., Nelson, B. W., \& Saleska, S. R. (2018). Causes of reduced leaf-level photosynthesis during strong El Nino drought in a Central Amazon forest. Global Change Biology, 14, 42664279. doi:10.1111/gcb.14293

Sharkey, T. D., Bernacchi, C. J., Farquhar, G. D., \& Singsaas, E. L. (2007). Fitting photosynthetic carbon dioxide response curves for C(3) leaves. Plant, Cell and Environment, 30(9), 10351040. doi:10.1111/j.1365-3040.2007.01710.x

Shuttleworth, W. J. (1984). Observations of radiation exchange above and below Amazonian forest. Quarterly Journal of the Royal Meteorological Society, 110(466), 1163-1169. doi:10.1002/qj.49711046623

Silvestrini, M., Válio, I. F. M., \& Mattos, E. A. d. (2007). Photosynthesis and carbon gain under contrasting light levels in seedlings of a pioneer and a climax tree from a Brazilian Semideciduous Tropical Forest. Brazilian Journal of Botany, 30, 463-474. doi:10.1590/S0100-84042007000300011

Slot, M., \& Winter, K. (2017). In situ temperature response of photosynthesis of 42 tree and liana species in the canopy of two Panamanian lowland tropical forests with contrasting rainfall regimes. New Phytologist, 214(3), 1103-1117. doi:10.1111/nph.14469 
Stahl, C., Burban, B., Wagner, F., Goret, J.-Y., Bompy, F., \& Bonal, D. (2013). Influence of seasonal variations in soil water availability on gas exchange of tropical canopy trees. Biotropica, 45(2), 155-164. doi:10.1111/j.1744-7429.2012.00902.x

Swaine, M. D., \& Whitmore, T. C. (1988). On the Definition of Ecological Species Groups in Tropical Rain Forests. Vegetatio, 75(1-2), 81-86. doi:10.1007/Bf00044629

ter Steege, H., Pitman, N. C. A., Sabatier, D., Baraloto, C., Salomão, R. P., Guevara, J. E., . . Silman, M. R. (2013). Hyperdominance in the Amazonian Tree Flora. Science, 342(6156). doi:10.1126/science.1243092

Théry, M. (2001). Forest light and its influence on habitat selection. Plant Ecology, 153(1-2), 251261. doi:10.1023/A:1017592631542

Tianxiang, L., Ronald P., N., Hanqin, T., Vörösmarty, C. J., Huazhong, Z., \& Shirong, L. (2002). A model for seasonality and distribution of leaf area index of forests and its application to China. Journal of Vegetation Science, 13, 817-830.

Urban, O., Holub, P., \& Klem, K. (2017). Seasonal courses of photosynthetic parameters in sunand shade-acclimated spruce shoots. Beskydy, 10(1-2), 49-56. doi:10.11118/beskyd201710010049

van de Weg, M. J., Meir, P., Grace, J., \& Ramos, G. D. (2012). Photosynthetic parameters, dark respiration and leaf traits in the canopy of a Peruvian tropical montane cloud forest. Oecologia, 168, 23-34. doi:10.1007/s00442-011-2068-z)

Van Der Meer, P. J., Sterck, F. J., \& Bongers, F. (1998). Tree seedling performance in canopy gaps in a tropical rain forest at Nouragues, French Guiana. Journal of Tropical Ecology, 14(2), 119-137. doi:10.1017/S026646749800011X 
Van Langenhove, L., Depaepe, T., Vicca, S., van den Berge, J., Stahl, C., Courtois, E., ... Janssens, I. A. (2019). Regulation of nitrogen fixation from free-living organisms in soil and leaf litter of two tropical forests of the Guiana shield. Plant and Soil. doi:10.1007/s11104-01904012-1

Ventre-Lespiaucq, A., Flanagan, N. S., Ospina-Calderon, N. H., Delgado, J. A., \& Escudero, A. (2018). Midday Depression vs. Midday Peak in Diurnal Light Interception: Contrasting Patterns at Crown and Leaf Scales in a Tropical Evergreen Tree. Frontiers in Plant Science, 9, 727. doi:10.3389/fpls.2018.00727

[dataset]Verryckt, L. T., Ellsworth, D. S., Vicca, S., Van Langenhove, L., Peñuelas, J., Ciais, P., . .. Janssens, I. A. (2020). Data from: Can light-saturated photosynthesis in lowland tropical forests be estimated by one light level? . Dryad Digital Repository. https://doi.org/10.5061/dryad.5hqbzkh39

Walters, M. B., \& Field, C. B. (1987). Photosynthetic light acclimation in two rainforest Piper species with different ecological amplitudes. Oecologia, 72(3), 449-456. doi:10.1007/bf00377578

Weerasinghe, L. K., Creek, D., Crous, K. Y., Xiang, S., Liddell, M. J., Turnbull, M. H., \& Atkin, O. K. (2014). Canopy position affects the relationships between leaf respiration and associated traits in a tropical rainforest in Far North Queensland. Tree Physiology, 34(6), 564-584. doi:10.1093/treephys/tpu016

Wickham, H. (2009). ggplot2: Elegant Graphics for Data Analysis. : Springer-Verlag New York. Wu, Z., Dijkstra, P., Koch, G. W., Peñuelas, J., \& Hungate, B. A. (2011). Responses of terrestrial ecosystems to temperature and precipitation change: a meta-analysis of experimental 
manipulation. Global Change Biology, 17(2), 927-942. doi:10.1111/j.13652486.2010.02302.x

Yoda, K. (1974). Three-dimensional distribution of light intensity in a tropical rain forest of West Malaysia. Japanese Journal of Ecology, 24(4), 247-254. doi:10.18960/seitai.24.4_247

Zhu, Z., Piao, S., Myneni, R. B., Huang, M., Zeng, Z., Canadell, J. G., . . . Zeng, N. (2016). Greening of the Earth and its drivers. Nature Climate Change, 6(8), 791-795. doi:10.1038/nclimate3004

\section{FIGURE LEGENDS}

FIGURE 1 Normalized leaf net photosynthesis $\left(A_{n}\right)$ in response to light (PPFD; $\mu \mathrm{mol} / \mathrm{m}^{2} / \mathrm{s}$ ), averaged over a set of eight tropical tree species (10 trees in total) and a total of 23 leaves measured at the Nouragues site for (a) top sunlit leaves ( $\mathrm{n}=15$ leaves), (b) middle canopy foliage ( $(n=3)$ and (c) lower canopy foliage $(n=5)$, and a set of 15 tropical tree species (17 trees and 12 saplings) and a total of 44 leaves measured at the Paracou site for (d) top sunlit leaves (n $=13$ leaves $)$, (e) lower canopy foliage $(n=19)$ and (f) saplings $(n=12)$. The error bars are the standard errors of the mean. The black filled points, underlined with a black line, indicate the light saturation range, which is the range of PPFD levels at which $A_{n}$ is light saturated and for which the points do not significantly differ from each other $(p>0.05)$. The slope between these data points is not significantly different from zero. The inset is a zoom of the main figure for which normalized $A_{n}$ ranges between 0.85 and 1 .

FIGURE 2 Normalized mean of leaf net photosynthesis $\left(A_{n} ; \mu \mathrm{mol} / \mathrm{m}^{2} / \mathrm{s}\right)$ in response to light (PPFD; $\left.\mu \mathrm{mol} / \mathrm{m}^{2} / \mathrm{s}\right)$ for seven pioneer trees $(\mathrm{n}=7)$. The error bars are the standard errors of the 
mean. Light-saturated leaf net photosynthesis was not reached according to the criteria for testing light saturation (see Methods).

FIGURE 3 Leaf-level net photosynthesis at $2000 \mu \mathrm{mol} / \mathrm{m}^{2} / \mathrm{s}\left(A_{s a t, 2000}\right)$ derived from a nonrectangular hyperbola based model (Eq. 2) in function of the leaf-level net photosynthesis at $1000 \mu \mathrm{mol} / \mathrm{m}^{2} / \mathrm{s}\left(A_{s a t, 1000}\right)$ derived from the measured data. $1000 \mu \mathrm{mol} / \mathrm{m}^{2} / \mathrm{s}$ is assumed to be at light saturation in this study since it is at the lower PPFD for which $A_{n}$ saturated here. Grey dots represent $A_{s a t, 1000}$ data that are within five percent from $A_{s a t, 2000}(\mathrm{n}=50)$. Yellow dots represent $A_{s a t, 1000}$ that are above $A_{s a t, 2000}+5 \%(\mathrm{n}=7)$. Blue dots represent $A_{\text {sat, } 1000}$ below $A_{s a t, 2000}-5 \%(\mathrm{n}=$

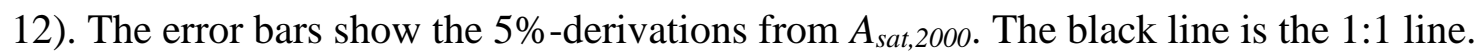

FIGURE 4 The stomatal conductance $\left(g_{s} ; \mathrm{mol} / \mathrm{m}^{2} / \mathrm{s}\right)$ measured at PPFD $=2000 \mu \mathrm{mol} / \mathrm{m}^{2} / \mathrm{s}$ compared to the stomatal conductance at the common saturating PPFD level of $1000 \mu \mathrm{mol} / \mathrm{m}^{2} / \mathrm{s}$ $(\mathrm{n}=68) .56$ points are above the 1:1 line (black line), and 12 are below the 1:1 line. 
Figure 1
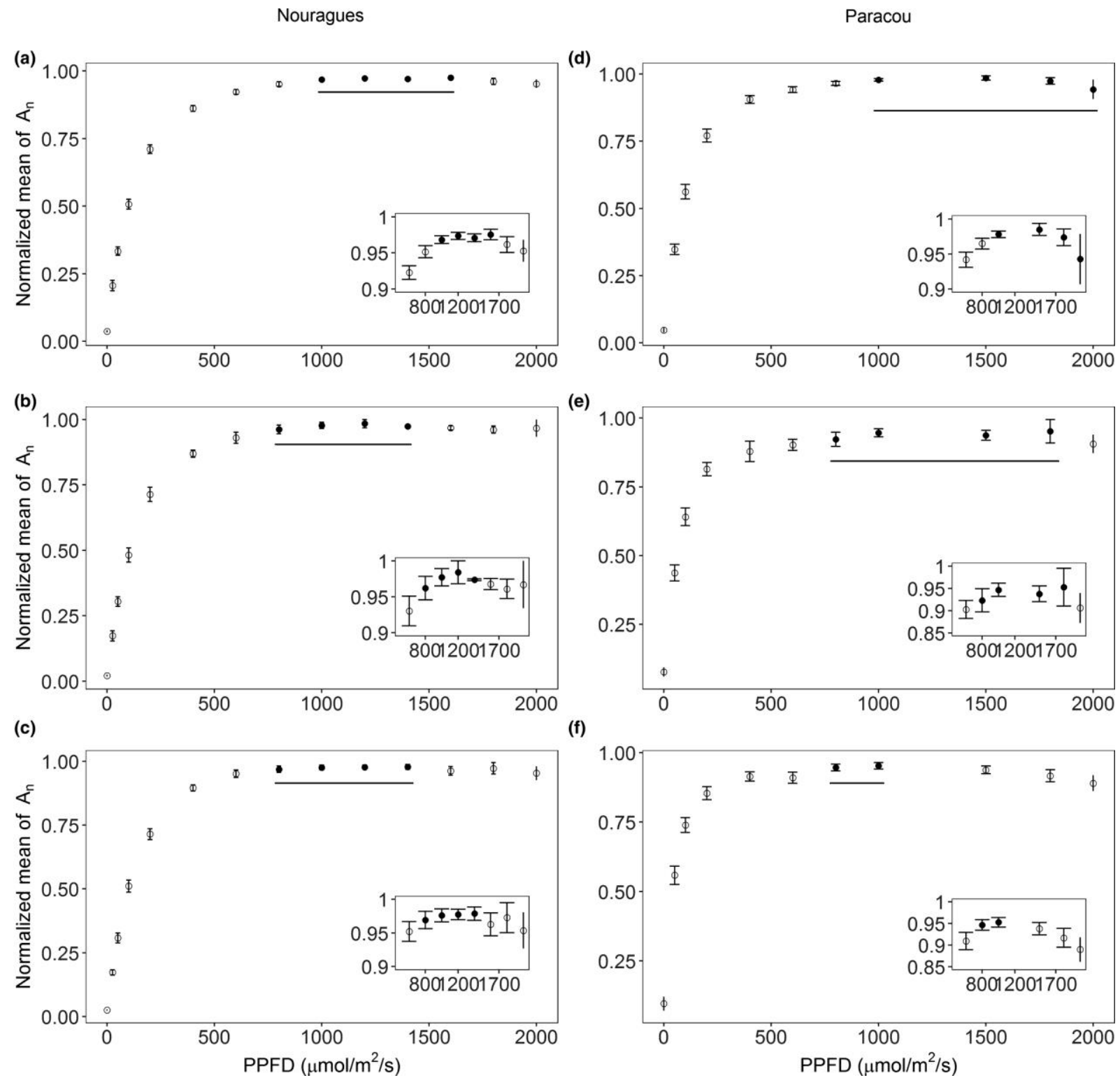
Figure 2

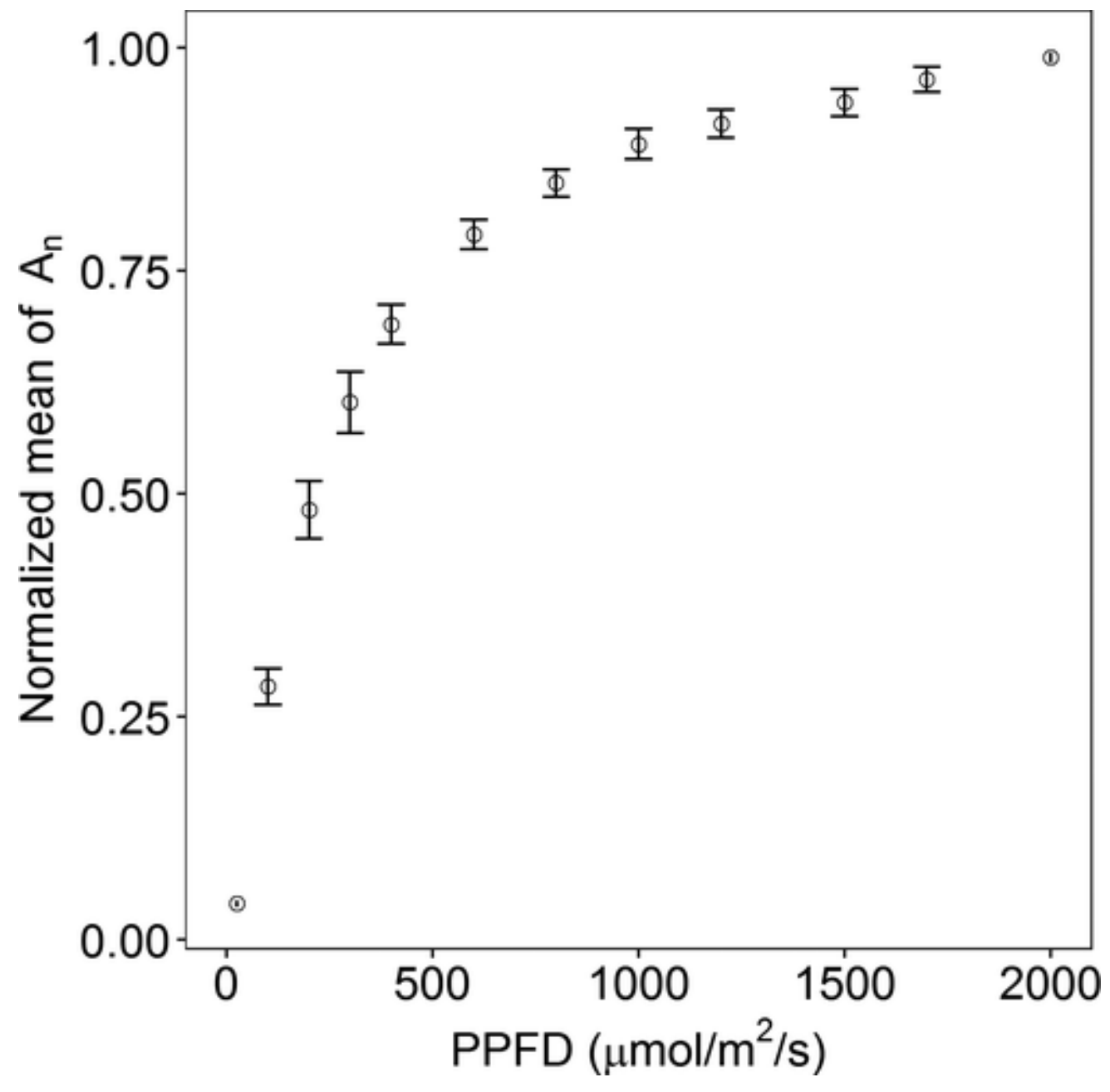


Figure 3

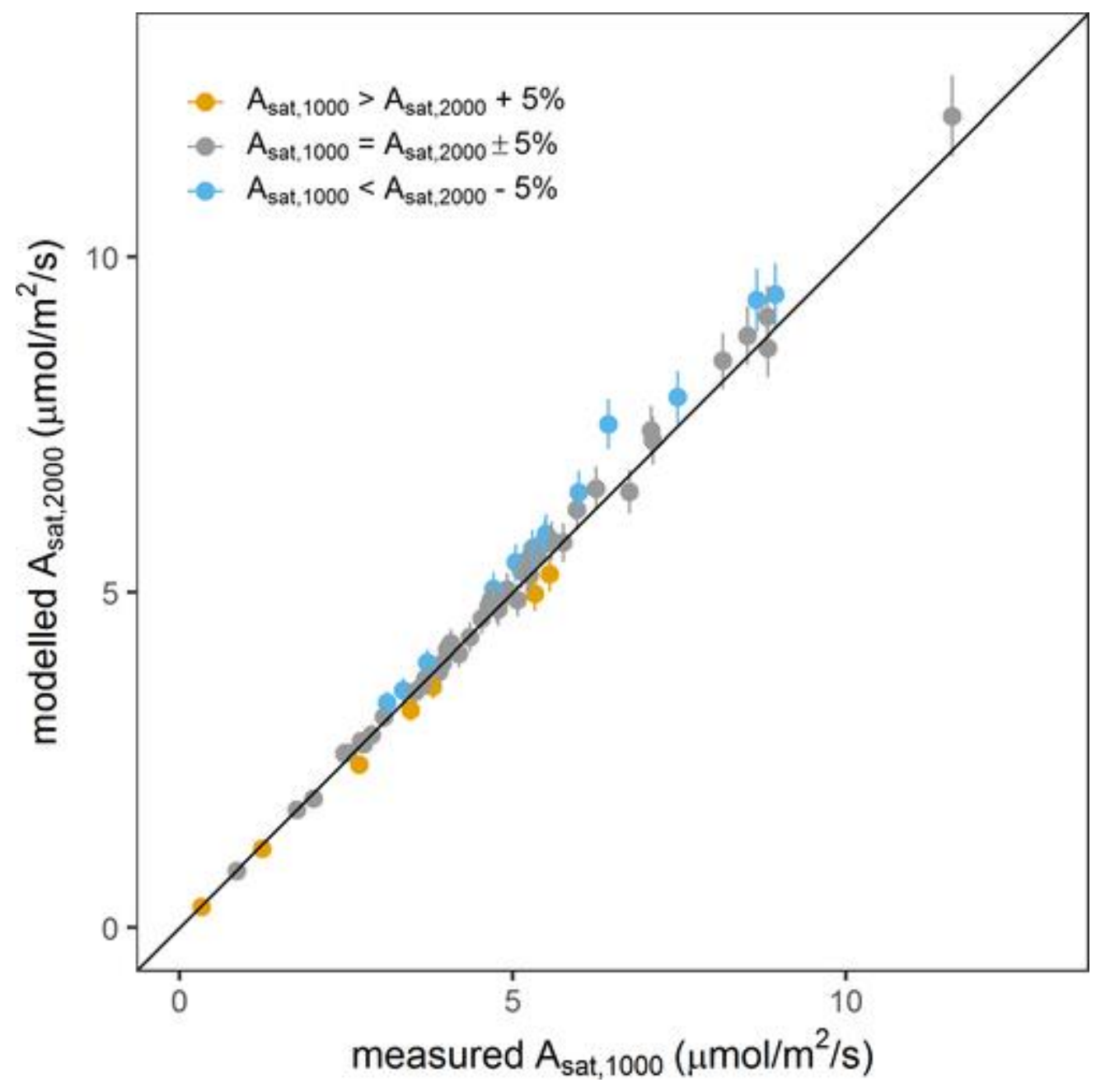


Figure 4

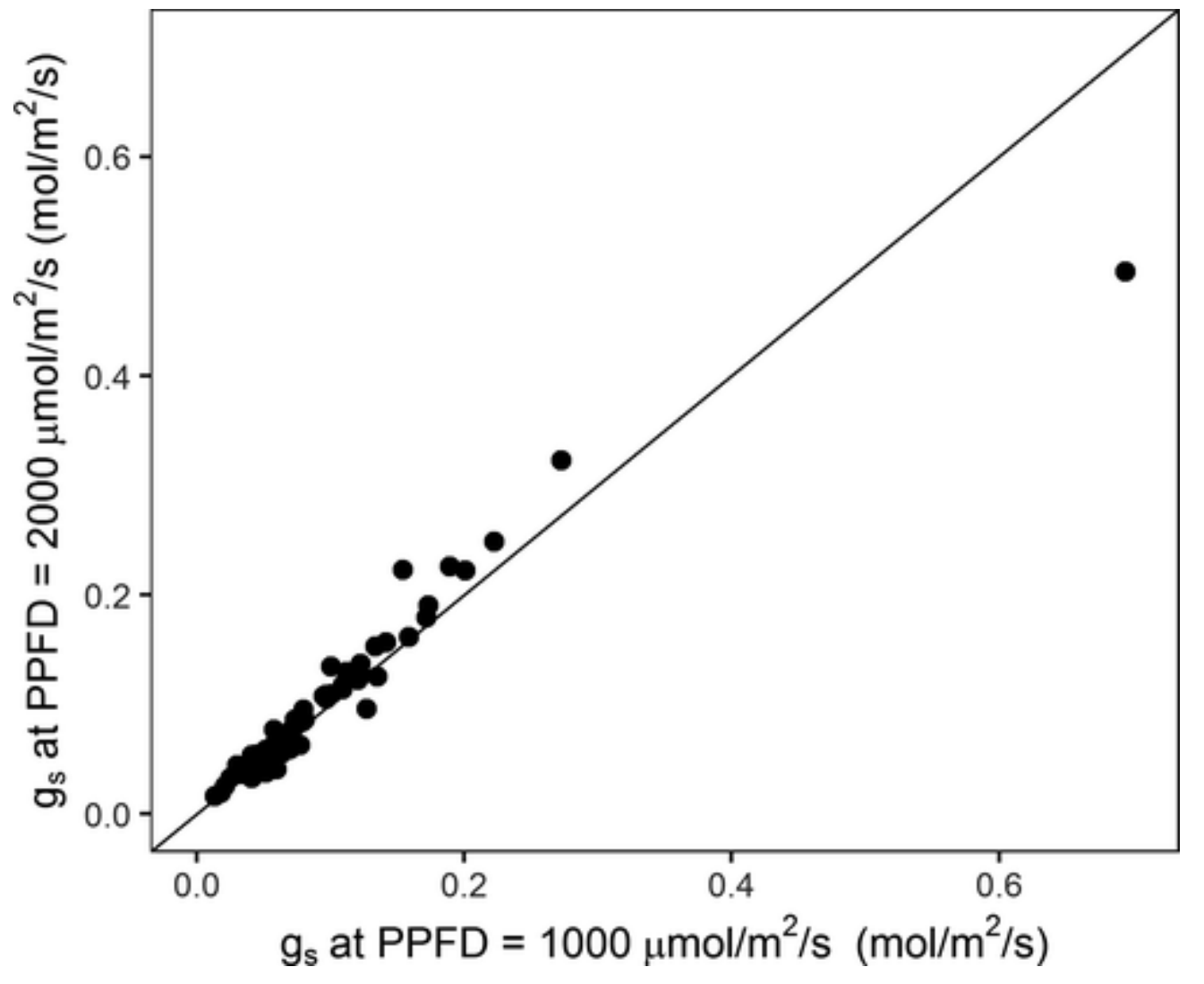

